\title{
SERVANTS OR MASTERS? LINGUISTIC AIDS IN LEGAL INTERPRETATION
}

¿SIRVIENTES O AMOS? AYUDAS LINGÜÍSTICAS EN LA INTERPRETACIÓN JURÍDICA

\section{Paulina Konca*}

\begin{abstract}
This paper presents the role of some intrinsic sources in legal interpretation. Some of linguistic aids follow from provisions of the law and other from the commonly accepted ruling practice or views expressed in literature. The position of those aids was verified through the analysis of case-law, literature, and provisions of law. The first section and second section focus on the priority of plain meaning rule and intrinsic sources in legal interpretation which is strongly emphasized in legal literature, caselaw and the interpretative provisions of many countries. Next, it presents how certain linguistic tools work in case law practice, what problems they can cause and what problems they can solve. The third point addresses the use of dictionaries as tools of linguistic interpretation. The fourth section explores the role of selected interpretative canons often found in legal regulations and case law practice: ordinary meaning canon, gender/number canon, ejusdem generis canon, presumption of consistent usage and prefatory-materials canon. It is concluded that the priority of a linguistic interpretation is not absolute and can never be understood as its exclusivity. Linguistic tools are not in themselves determinants of correct meaning. In order to make a correct interpretation, it is necessary not to be guided, by indications labelled as objective, sometimes artificially imposed, but by the
\end{abstract}

\footnotetext{
* Ph.D. candidate, University of Silesia (Katowice, Poland). The research carried out in order to elaborate this text have been financed from the fund of the Polish National Science Centre-Narodowe Centrum Nauki (NCN) within the framework of research project number 2018/29/N/HS5/00648. https://orcid.org/0000-0003-1532-8693. paulinakonca@ gmail.com
} 
intention of the legislator, which such tools may discover and should only be used for that purpose.

Keywords: Dictionaries, Interpretive Resources, Intrinsic Aids, Law of Interpretation, Linguistic Canons

Resumen: Este artículo presenta el papel de algunas fuentes intrínsecas en la interpretación jurídica. Algunas de las ayudas lingüísticas se derivan de las disposiciones de la ley y otras de la práctica normativa comúnmente aceptada o de las opiniones expresadas en la literatura. La posición de esas ayudas se verificó mediante el análisis de la jurisprudencia, la literatura y las disposiciones legales. La primera y la segunda sección se centran en la prioridad de la regla de sentido llano y las fuentes intrínsecas en la interpretación, lo que se enfatiza fuertemente en la literatura jurídica, la jurisprudencia y las disposiciones interpretativas de muchos países. A continuación, presenta cómo funcionan determinadas herramientas lingüísticas en la práctica de la jurisprudencia, qué problemas pueden causar y resolver. El tercer punto aborda el uso de diccionarios como herramientas de interpretación lingüística. La cuarta sección explora el papel de los cánones interpretativos seleccionados que a menudo se encuentran en las regulaciones legales y la práctica de la jurisprudencia: canon de significado ordinario, canon de género/número, canon ejusdem generis, presunción de uso consistente y canon de materiales preliminares. Se concluye que la prioridad de una interpretación lingüística no es absoluta y nunca puede entenderse como su exclusividad. Las herramientas lingüísticas no son en sí mismas determinantes del significado correcto. Para hacer una interpretación correcta, es necesario no guiarse por indicaciones etiquetadas como objetivas, a veces impuestas artificialmente, sino por la intención del legislador, que tales herramientas puedan descubrir y sólo deben ser utilizadas para tal fin.

Palabras clave: Diccionarios, Recursos interpretativos, Ayudas intrínsecas, Ley de interpretación, Cánones lingüísticos

Summary. I. Introduction. II. Priority of Plain Meaning Rule and Intrinsic Sources in Legal Interpretation. III. Dictionaries. IV. Linguistic Canons of Interpretation. IV.1. Ordinary Meaning Canon/Plain Meaning Rule. IV.2. Gender/Number Canon. IV.3. Ejusdem generis. IV.4. Presumption of Consistent Usage. IV.5. PrefatoryMaterials Canon. V. Language and intention. VI. Conclusions. References. 


\section{INTRODUCTION}

The starting point for any interpretation is intrinsic sources, principally the words (Jellum \& Hricik, 2009, pp. 33-34). All interpretation should start with the text of the statute (Jellum, 2008, p. 61). It is obvious that even in the purposivism concepts that do not assume any formal hierarchy of interpretive actions, the reading of the legal text cannot be omitted.

The priority of linguistic interpretation is reflected in the legal acts that govern legal interpretation, as well as in case law. A reading of the rules and judgments, which show that non-linguistic interpretation is only the exception the interpreter uses when the text is not clear, suggests that, in general, the rules of law are read in the ordinary sense and knowledge of language conventions is sufficient to be able to rely on them. However, the situation is more complex. There is no doubt that meaning is only revealed in context, otherwise we can only speak of utterance meaning. Thus, how can the primacy of linguistic interpretation be understood, which is often referred to by legislators and judges?

Firstly, I would like to present some regulations and rulings setting out the hierarchy of actions, which is headed by the use of intrinsic sources. Next, I would like to refer to selected linguistic canons and to the role of dictionaries in interpreting the law, as dictionaries are one of the tools that help interpreters determine the meaning of the words used in legal provisions.

In this paper I refer to the normative regulations of Australia, Chile, Colombia, Ecuador, Spain, Ireland, the Maldives, the United States, Uruguay and Italy and I also make reference to the Polish and Spanish case law and studies on case law of selected common law countries. There is no doubt that the discussed systems are diverse - they are countries of different continents and different traditions and legal cultures (civil law and common law). However, the differences that exist between them do not make it impossible to compare them. First of all, I am aware of the differences in the discussed systems, but I do not compare whole systems, but only their chosen aspect (the role of language tools in their interpretation regulations). Secondly, all the differences mentioned above do not matter much in this aspect. What is important is that among the interpretation directives under discussion, the significant position of language tools in interpreting is strongly emphasized. The text of the provision comes from the legislator, and in all the countries concerned the law is created by way of legislation ${ }^{1}$.

\footnotetext{
${ }^{1}$ Of course, in common law countries, the precedent is a separate source of law, which does not, however, deprive the written law of its significant position.
} 
There is also another important similarity between the countries in question. The language directives, that are the main focus of my analysis, are reflected in the statutory provisions of the analyzed systems. The only exception in this context is Poland. In Poland there are no interpretative regulations ${ }^{2}$, therefore when discussing Polish conditions, I will focus mainly on the jurisprudence, which, apart from literature, is the only source of interpretative directives in Poland.

\section{PRIORITY OF PLAIN MEANING RULE AND INTRINSIC SOURCES IN LEGAL INTERPRETATION}

Legislative acts regulating legal interpretation, such as civil codes or interpretation acts, usually indicate the priority of the intrinsic sources, especially the plain meaning rule, in the process of legal interpretation.

To give some examples, article 12 of the Italian Preliminary Provisions of the Civil Code provides that, in applying law, no meaning may be attributed to that law other than that which actually results from the proper meaning of the words used, depending on their relationship and the intention of the legislature. The first part of article 3.1 of the Spanish Civil Code also says that the legal provisions are to be interpreted in accordance with the proper meaning of the words they contain.

Most of the Latin American civil codes state that the words in legal provisions are to be understood in accordance with their natural and obvious meaning, according to the common use of those words. However, when the legislature has defined them directly for specific matters, they have a meaning consistent with the legal definition ${ }^{3}$. Technical words and terms of art or science are to be understood in the sense defined by those who deal with that science or art, unless it is clear that they have been used in another sense $^{4}$. The interpretative rules contained therein treat the role of context in the interpretation of the law, especially the need to refer to each of the individual words used in the rule, the rules of the written language, and sometimes also other legal regulations. They also indicate that the context of written law is to clarify the meaning of its constituent elements so as to

\footnotetext{
2 There are regulations concerning the interpretation of contracts and wills, but not statutory law.

${ }^{3}$ See Art. 28 of the Colombian Civil Code, Art. 20 of the Chilean Civil Code, Art. 18 (2) of the Ecuadorian Civil Code, Art. 18 of the Uruguayan Civil Code.

${ }^{4}$ See Art. 29 of the Colombian Civil Code, Art. 21 of the Chilean Civil Code, Art. 18 (3) of the Ecuadorian Civil Code, Art. 19 of the Uruguayan Civil Code.
} 
ensure proper coherence and harmony ${ }^{5}$. Unclear parts can be read in the light of other regulations, especially if they concern the same issues ${ }^{6}$.

Also article $5^{\text {th }}$ of the Irish Interpretation Act 2005 gives priority to the linguistic interpretation by stating that in construing a provision of any Act (other than a provision that relates to the imposition of a penal or other sanction) that is obscure or ambiguous, or that on a literal interpretation would be absurd or would fail to reflect the plain intention of the Oireachtas the provision shall be given a construction that reflects the plain intention of the Oireachtas or parliament concerned, as the case may be, where that intention can be ascertained from the Act as a whole.

In accordance with the section $15 \mathrm{AB}$ of the Australian Acts Interpretation Act (1901) in the interpretation of a provision of an Act, if any material not forming part of the Act is capable of assisting in the ascertainment of the meaning of the provision, consideration may be given to that material: to confirm that the meaning of the provision is the ordinary meaning conveyed by the text of the provision taking into account its context in the Act and the purpose or object underlying the Act; or to determine the meaning of the provision when the provision is ambiguous or obscure; or when the ordinary meaning conveyed by the text of the provision taking into account its context in the Act and the purpose or object underlying the Act leads to a result that is manifestly absurd or is unreasonable.

Also, many state legislatures in the United States have chosen the textualist approach that focuses on intrinsic sources, particularly on the text, to discern the meaning of the language actually used (Jellum, 2008, pp. 1621). For instance, the Connecticut provision states that the meaning of a statute shall, in the first instance, be ascertained from the text of the statute itself and its relationship to other statutes. If, after examining such a text and considering such a relationship, the meaning of the text is plain and unambiguous and does not yield absurd or unworkable results, extratextual evidence of the meaning of the statute shall not be considered ${ }^{7}$. However, it must be underlined that, even in the intentionalist approach, the reading of the text is always the starting point of the interpretation. Even in New York, which adopted intentionalism, regarding which the primary consideration of the courts in the construction of statutes is to ascertain and give effect to the intention of the Legislature, the intention is first to be sought from a literal reading of the act itself (pp. 21-25).

\footnotetext{
${ }^{5}$ See Art. 30 of the Colombian Civil Code, Art. 22 of the Chilean Civil Code, Art. 18 (4) of the Ecuadorian Civil Code, Art. 20 of the Uruguayan Civil Code.

${ }^{6}$ See Art. 30 of the Colombian Civil Code, Art. 18 (4) of the Ecuadorian Civil Code.

${ }^{7}$ CT Gen Stat $\S 1-2 z(2013)$.
} 
In Poland, the presumption of an ordinary usage is sometimes even called by the judiciary «the most important rule of the linguistic interpretation» (Decision of the Supreme Court of 5-XII-2013, file II KK 212/13; Sentence of the Voivodeship Administrative Court in Wrocław of 14-VI-2011, file I SA/Wr 443/11, LEX no 991946) ${ }^{8}$. Writing about Polish doctrine, I cannot fail to refer to the clarificative theory of juristic interpretation created in the 1950s by Jerzy Wróblewski (1959). According to the most common understanding of the clara non sunt interpretanda canon, if the application of rules of linguistic interpretation has led to the clarification of interpretation doubts, there is no need to apply the rules of systematic or functional interpretation (Morawski, 2002, pp. 63-64). Dozens of rulings of the Polish courts refer to that principle 9 .

Although the rule is sometimes regarded as controversial, since, according to many, every text, whether clear or not, needs to be interpreted, there is above all a practical justification, as it would be difficult for a court to take complex interpretative steps in all cases of application of legal provisions (Morawski, 2002, pp. 66-67). Occasionally, it is pointed out that this paremia can only be understood as interpretatio cessat in claris, so the principles that deal not with the limits of the beginning of the interpretation but with the limits of its end (Chodun \& Zieliński, 2009, p. 86).

Undoubtedly, the courts should not invoke linguistic clarity when the parties to a dispute understand the rule differently or when there are two

${ }^{8}$ Decision of the Supreme Court of 5-XII-2013, file II KK 212/13, OSNKW 2014/5/38; Sentence of the Voivodeship Administrative Court in Wrocław of 14-VI-2011, file I SA/Wr 443/11, LEX n ${ }^{\circ} 991946$.

${ }^{9}$ For example, it is enough to indicate here some of them: «The statutory provisions concerning the formal requirements of a complaint and the consequences of an incomplete complaint are therefore unambiguous (clara non sunt interpretanda)» (Order of the Supreme Administrative Court of 20-I-2011, II GSK 1496/10, LEX n ${ }^{\circ}$ 742900); "The content of these two provisions is perfectly clear and does not require interpretation (clara non sunt interpretanda)» (Supreme Court sentence of 16-V-2003, II KK 65/03, LEX n ${ }^{\circ}$ 78379); «This provision does not require any interpretive measures to understand its content (clara non sunt interpretanda)» (Sentence of the Supreme Administrative Court of 22-XI2005, ref. II FSK 1058/05, LEX n ${ }^{\circ}$ 849612); «An interpretation is only necessary if there is reasonable and objective doubt about the understanding of the provision, otherwise the interpretation becomes redundant (clara non sunt interpretanda)» (Sentence of the Supreme Administrative Court of 12-X-2017, I OSK 829/17, LEX n 2404398». In addition,

«The authorities of both instances misinterpreted the provision of Art. 17 (1) of the Act on Family Benefits. They did so in breach of the rules of interpretation of the law, violating the rule "clara non sunt interpretanda", according to which a clear provision does not need to be interpreted» (Sentence of the Voivodeship Administrative Court in Białystok of 8-XI-2018, II SA/Bk 547/18, LEX n 2576541). 
competing case law lines. In such situations invoking linguistic clarity is useless. Doubts are a proof that the rule is not clara and it is not about the doubts that a judge feels, but about the situation where divergent interpretative hypotheses exist.

The Polish literature indicates the following order of application of the basic language guidelines: first, reference should be made to this meaning, which was indicated by the legislator itself in the legal definition (ibíd., p. 89-90). This first rule is beyond doubt.

«The conviction of the binding nature of legal definitions prevails among lawyers, especially in those cases where a legal definition clearly changes the hitherto meaning of a word or phrase in the existing language. If the legislator has the power to prescribe certain behavior in a given area, it is undoubtedly competent to define the meaning of the terms by which the injunction is formulated» (Ziembiński, 1980, p. 311).

In the absence of a definition, the meaning of the terms to which the interpreting authority is bound by an interpretative decision of a higher authority should then be referred to the legal language if it is a legal term and there is a uniform understanding of the phrase being interpreted in the legal language. As far as factual terms are concerned, reference should be made to such understanding on which there is common agreement in the legal language of the area concerned, and in the case of other factual terms to the general Polish language (Chodun \& Zieliński, 2009, pp. 89-90).

Given the fundamental role that intrinsic sources play in the interpretation process, I would like to briefly refer to some of them below: dictionaries and several linguistic canons and, subsequently, assess whether the language itself can ever respond to the interpreter's doubts.

\section{DICTIONARIES}

One of the basic linguistic aids is the dictionary, which may be used to find the ordinary meaning of words (Andreucci Aguilera, 2008, p. 27), usually confirming the interpreter's linguistic intuition. The authors draw attention to two types of problems that are related to the use of dictionaries by interpreters: so-called external problems, such as age and type of dictionary, i.e., issues related to the selection of the right dictionary to be used by the interpreter and so-called internal problems related to definitions and defining (Czelakowska, Kubicka \& Klubińska, 2016, p. 55). 
On the whole, selecting a dictionary is not an easy task. There are innumerable types of dictionaries: linguistic, specialized (e.g., of natural sciences, technical), phraseological, foreign word, encyclopedic, etymological, archaic, thesaurus etc. An important division is that into prescriptive dictionaries, which are limited to indicating the linguistic phenomena compatible with the language standard in force, as opposed to descriptive dictionaries, which characterize language units on the basis of how they have been actually used (Żmigrodzki, 2003, p. 26).

The Maldivian legislature indicates that the manner in which the word is used in a reliable dictionary may be used in order to determine the meaning of a certain word, words or sentence in such an $\mathrm{Act}^{10}$. It seems that although a similar requirement has not been formulated in other legislation, there is no doubt that the interpreter should refer to a reliable dictionary. Polish literature points out that the use of a random dictionary can do more harm than good (Bielska-Brodziak, Tobor \& Żmigrodzki, 2008a, pp. 79-95; Bielska-Brodziak, Tobor \& Żmigrodzki, 2008b, pp. 3-13; Żurowski, 2014, pp. 55-75; Żurowski, 2015, pp. 29-40). It also notes that, for example, the Polish Supreme Administrative Court in the period July 2004 - December 2005 quoted 21 dictionaries in 35 rulings, which shows a complete lack of consensus on the choice of dictionaries (Bielska-Brodziak \& Tobor, 2007, p. 32).

Therefore, the question remains: what kind of dictionary can be considered reliable? It is worth noting that although the use of a dictionary is a good starting point in many interpretation situations, the decision to use a certain dictionary «should be preceded by a certain minimum quantum of knowledge in lexicography» (Bielska-Brodziak, Tobor \& Żmigrodzki, 2008a, p. 95). The best linguistic dictionary for an interpreter is a dictionary with a decent material illustration, carefully and relatively recently developed (ibid.), although sometimes, on the contrary, it is thought that the dictionary should not have been published at a time remote from when the statute was written (Popkin, 2007, p. 62).

The literature indicates that it is better to avoid thesaurus, as it is not easy to find a dictionary that would make it possible to establish the actual equivalence, rather than just the closeness, of the words, whereas regarding the meaning of terms of art and science, the terminology dictionaries of that discipline should be used (Bielska-Brodziak, Tobor \& Żmigrodzki, 2008a, p. 95). It is also worth verifying the interpretative hypothesis on the basis of other sources, like other dictionaries or encyclopedias (ibid., p. 93). The external problem is therefore complex and, unless the legislator decides itself, the

${ }^{10}$ Art. 11, point b, of the Maldivian Interpretation Act. 
courts must take into account a number of factors when choosing a dictionary that will allow them to use the best possible tool in a given situation.

The external problem was eliminated in Spain. In the Spanish "Directrices de técnica normativa" ("Rules of normative technique"), in the part relating to linguistic criteria, the legislature expressly provides that texts are to be edited in accordance with the grammatical and spelling standards developed by Real Academia Española (RAE) and contained in the RAE dictionary" ${ }^{11}$. This disposition of the Spanish "Directrices de técnica normativa" eliminates an external problem regarding the use of dictionaries. Spanish courts often use the RAE dictionary. A separate project from this dictionary is the "Diccionario del español jurídico", created by RAE in collaboration with the Consejo General del Poder Judicial.

It should be noted that the use of a dictionary to check or prove a certain meaning is based on the assumption that the legislator used the chosen terms, understanding them in the way indicated in the dictionary. Depending on the country, the dictionary may be a stronger or weaker proof of intent. The establishment of an official dictionary definitely strengthens the position of this tool.

However, the conscious choice of a dictionary is only "half the success". It is also crucial how the interpreter uses the dictionary. A dictionary's function is to provide a variety of possible meanings. What can be a problem for an interpreter is that the context is often lacking (Popkin, 2007, p. 62). Sławomira Wronkowska and Maciej Zieliński (2001), in the context of the requirement to search for the basic meaning of the words used by the legislator, order the interpreter who uses the dictionary to choose the first or one of the first meanings proposed in the dictionary (Wronkowska \& Zieliński, 2001, p. 44; Wierczyński, 2016, p. 97). Nevertheless, it is worth mentioning that «all may agree that a particular word is employed with certain meanings, but there may be disagreement whether other meanings are merely less common or are wrong. There is also the argument about whether a lexicographer's judgment is more worthy of acceptance than that of any other cultivated person» (Rynd, 1991, p. 716). It results from the fact that «words sometimes are used with clear and distinct meaning, and

\footnotetext{
11 Just to mention a few rulings: Sentence of Tribunal Supremo of 26 June 2020 (STS 1963/2020); Sentence of Audiencia Nacional, Sala de lo Social, of 16 June 2020 (SAN 1162/2020); Sentence of Tribunal Superior de Justicia de Galicia, Sala de lo Social, of 10 June 2020 (STSJ GAL 2509/2020); Sentence of Tribunal Superior de Justicia de Cataluña, Sala de lo Contencioso, of 15-V-2020 (STSJ CAT 2114/2020); Sentence of Tribunal Supremo, Sala de lo Penal, of 7-V-2020 (STS 1298/2020); Sentence of Tribunal Supremo, Sala de lo Social, of 11-III-2020 (STS 1145/2020); Sentence of Tribunal Superior de Justicia de Cataluña, Sala de lo Civil y Penal, of 24-II-2020 (STSJ CAT 90/2020).
} 
sometimes not. Some usages are incorrect, and there are degrees and shades of precision ranging from the most predictable usage (jargon) to the most unusual and imaginative (poetry)» (ibíd.).

The literature analyzing the United States Supreme Court's longstanding case-law based on dictionaries underlines that:

«The Court should rely on dictionaries in beginning its definition of terms to help fully exhaust all possible definitions of what the sender may have meant the message to mean, or how the receiver could have construed the message. Then, the Court should use other factors such as context, conduct, purpose and history to determine the appropriate meaning. This approach properly reflects the limits of dictionaries, the importance of construing language in context and, if correctly applied, should result in decisions accurately reflecting the appropriate definition of the term to be defined» (Kirchmeier \& Thumma, 1999, p. 301).

The dictionary itself will not give a certain answer to the questions the interpreter is asking - the answer can only appear when the search is given the proper context. Detaching the definition of words from the context in which these words appear in the law may lead to manipulation.

The interpreter should also bear in mind that the meaning at the moment the statute is passed is not necessarily the same as the current usage of the word concerned. The dynamics of social reality affects many issues, including the way the words used in statutory prescriptions are understood. Many interpretive provisions refer to that issue. One of the provisions of the Irish Interpretation Act points out that in construing a provision of any Act or statutory instrument, a court may make allowances for any changes in the law, social conditions, technology, the meaning of words used in that Act or statutory instrument and other relevant matters, which have occurred ${ }^{12}$. The Maldivian legislator says that where a particular word conveys a special, popular or widely used meaning at that point in time, the meaning prevalent in society at that time shall be preferred instead of its actual, original, or conceptual meaning ${ }^{13}$. It seems that the best solution is to decide de casum ad casum, giving the words their fair meaning in context.

\section{LINGUISTIC CANONS OF INTERPRETATION}

Among the various divisions of interpretative canons, the differences between institutional, linguistic and substantive canons can be distinguished (Popkin, 2007, pp. 17-21). Linguistic canons are also a diverse group.

${ }^{12}$ Art. 6 of the Irish Interpretation Act of 2005.

${ }^{13}$ Art. 12, point g, of the Maldivian Interpretation Act.

Ius Humani | v. 10 (I) (2021), p. 82 
Sometimes the literature discusses the so-called simple language rules, the application of which, in relation to the term in question, does not involve considering it in any context (Municzewski, 2004, pp. 38-39). It seems that such directives include mainly grammar rules. As an example of such a rule, it is sometimes indicated that a legal definition should be referred to (ibíd.), but it should be noted that the whole normative act is always a certain context - the definition itself is usually part of the macrocontext (Zieliński, 2002, p. 145). Examples of maxims emphasizing the relationship between the words used in a rule and their rational choice by the legislator are associated-words canon noscitur a sociis (Garner \& Scalia, 2012, pp. 195-198), ejusdem generis (ibíd., pp. 199-213; Popkin, 2007, pp. 74-75), surplusage canon per non est (Garner \& Scalia, 2012 pp. 174-179) or lege non distinguente ${ }^{14}$. Examples of traditionally used guidelines related to the construction of a legal act and interpretation of a provision in the context of the whole regulation are the prohibition of synonymous interpretation, prohibition of homonymous interpretation/presumption of consistent usage and less linguistic, more teleological, harmonious-reading canons or elephant-inmousehole doctrine. Discussing all the linguistic canons would require much more space than this work allows. Below, I will discuss some popular linguistic canons and their use by jurisprudence.

Before I move forward, I would like to point out that by most authors, interpretative canons are not considered as legal norms at all. Richard Posner (1993) compares the canons to proverbs and says that they «no more enable difficult questions of interpretation to be answered than the maxims of everyday life enable the difficult problems of everyday living to be solved» (p. 280). Michael Sinclair (2006), on the other hand, although he also does not recognize canons as law, stresses that they cannot be considered a mere cliché (pp. 921-922). Lawrence M. Solan (2014) also believes that equating canons with proverbs is too far-reaching. The canons have a certain authority because they usually come from the analysis presented by the courts of

14 Polish judicial practice provides many examples of the application of lege non distinguente rule. For instance, one of the Polish courts analyzed Art. 18, a (1), of the Polish Commercial Companies Code. That provision states that the municipal council controls the activities of municipal organizational units. The question arose as to which municipal organizational units were subject to municipal council control and which were not. As the court stated,

«Therefore, since Art. 18, a (1), of the Polish Commercial Companies Code does not differentiate between organizational units with or without legal personality, it should be considered that they concern both, in accordance with the principle lege non distinguente nec nostrum est distinguere» (Sentence of the Voivodship Administrative Court in Gorzów Wielkopolski of 28-XI-2018, II SA/Go 779/18, LEX n² 2592695). 
appeal as justification for their interpretation (p. 743). One of the most famous texts critically related to interpretative canons is the article by K.N.N. Llewellyn (1950), which presents pairs of dueling canons: thrusts and parries (p. 401). Empirical research has not fully confirmed that canons are simply a tool of manipulation, although of course using them does not always lead to homogeneous results (Krishnakumar, 2015, pp. 910-1006). It is difficult to avoid that in legal practice they are invoked as arguments for a convenient result for a party, but at the same time it is hard to consider them only as a certain tool of manipulation. If they are selected according to a clearly defined key, the risk of their random usage decreases. Moreover, although canons do not always help to solve interpretation problems, they can serve as useful guidelines and have been used as such for centuries, which is also acknowledged also by the authors who criticize them (Carston, 2013, pp. 32-33).

\section{IV.1. Ordinary Meaning Canon/Plain Meaning Rule}

As the examples mentioned above have shown, the ordinary meaning rule followed, unless otherwise defined by the legislature, is a fundamental semantic rule of interpretation and is widely accepted in the legal discourse of many countries, which is due to the fact that interpreters cannot be forced to «divine arcane nuances» or to «discover hidden meanings» (Garner \& Scalia, 2012, p. 69). After all, one of the basic requirements for legal texts is their communicativeness (Wronkowska \& Zieliński, 2012, p. 39).

However, even this assumption is not free of controversy. Some authors take the view that there is no such thing as «plain meaning» (Winter, 1990, p. 1468). But judges «are situated in a belief system that takes as "objective" what is only conventional» (ibíd.). Stanley Fish (2005) points out that «the plain meaning rule cannot be followed - there is no meaning apart from purpose, and purpose cannot be inferred from the words alonethat fact is of no interpretive interest whatsoever» (p. 646).

Some authors say that linguistic canons do not always solve interpretation problems - they often create them (González, 2011, pp. 583649). It should be noted that some of the provisions refer, at the same time, to plain meaning or clear meaning, as well as to literal understanding. For example, as stated in Article 19 of the Chilean Civil Code, when the meaning of a law is clear, its literal tenor will not be disregarded on the pretext of consulting its spirit, and it is not always known what the relationship between the two concepts is. We can interpret the first sentence of article 19 in such a way that «clear meaning» and «literal tenor» mean the same thing or mean different things. Again, the two interpretations seem plausible as 
both seem to have textual bases, but neither is strong enough to rule out other alternative (Núñez Vaquero, 2016, pp. 141-142).

It should be added that the respective position of the language canons is not always clear. This also applies to the usual meaning, which most of the rules and courts order to follow in the first place. For instance, «one can interpret language either in terms of the outer boundaries of a statutory term, or in terms of ordinary usage. Judges vacillate between the two approaches» (Solan, 2014, pp. 742-743).

It is noted in the literature that following the ordinary meaning involves a number of problems, such as whose meaning is at stake (Chodun \& Zieliński, 2009, pp. 85-86) or the meaning of which moment (of drafting or application of the rule) is to be taken into account (Lee \& Mouritsen, 2017, pp. 788-879). Literalism is not less manipulative than the other ways of interpreting statutes (Popkin, 2007, pp. 194-196). An analysis of the case law carried out by Anita Krishnakumar (2015) showed that «many interpretive tools that seem highly susceptible to competing invocationincluding legislative history, dictionary definitions, substantive canons, and statutory purpose - are generating only low levels of dueling (in roughly 25 percent of the relevant cases)», and, in a large percentage of cases, only two tools were used in a dueling manner: Supreme Court precedent and the plain meaning rule (pp. 959-960).

Using the usual meaning is undoubtedly a good starting point. It is the simplest, most natural, self-evident assumption that can be made. At the same time, like everything that seems obvious, it is largely intuitive and sometimes turns out to cause problems, not to solve them. That is why it is rather a poor argument in case of doubt, and thus in those situations where interpretation is needed.

\section{IV.2. Gender/Number Canon}

One of the linguistic canons that appear most frequently in civil codes and interpretation acts is the gender/number canon ${ }^{15}$. These guidelines are considered in the Anglo-Saxon literature to be one of the basic canons of semantic interpretation (Scalia \& Garner, 2012, pp. 129-131).

Issues related to the gender used in the legislation do not raise serious doubts in terms of interpretation, but rather in terms of drafting the legislation taking into account assumptions about gender neutrality (Zeifert, 2019, pp. 247-248). In the literature, it is noted that the grammatical number

\footnotetext{
${ }^{15}$ See Art. 23 of the Australian Acts Interpretation Act, Art. 6 of the British Interpretation Act of 1978, Art. 20 of the Civil Code of Ecuador, Art. 53-54 of the Loi d'Interprétation of Quebec.
} 
of the word is particularly problematic for interpreters (Zeifert, 2019, p. 230). The reference of a single word to multiple dignitaries is justified on the basis of an a fortiori conclusion and a finding that the generic expression used does not mean either individual objects or their classes, but rather an ideal object that becomes a reference point, while the reverse rule, especially in the case of provisions providing for criminal sanctions, raises objections (Zeifert, 2019, pp. 231-242). However, this rule is not strictly applied. It is worth noting that the Polish Supreme Court has given a comprehensive explanation of the withdrawal from this canon:

«The mere use of the plural in the content of a legal norm to define the object of direct protection, the object of causal action or a means of committing an offence does not mean that the legislator uses it in the sense of "at least two", "racial greyhounds or their hybrids" contained in the Act (...) also includes one dog of this breed or its hybrids (...) A review of the content of the disposition of legal norms contained in the provisions of the Criminal Code, as well as in the provisions of the Act, reveals a discrepancy in the use of the grammatical form of determining the number of the object to which the verb action relates. The object is generally defined in the singular, but occasionally there are cases of using the plural. The latter include, for example, the norms penalizing the behavior of the perpetrator who: "uses means" [Article 118 (2)], "in breach of (...) principles", "shall not use safety devices", "restricts the human being (...) in rights", (...), "destroy border signs", "produces false or fraudulent documents or unreliable written declarations". (...) It must be admitted that the use of the plural (...) may prima vista give rise to a suspicion of the normative significance of this procedure, (...) However, it is obvious that this does not yet entitle us to draw firm conclusions. The mere observation of this issue does not end the process of recognizing the content of the norm but is only a starting point for the necessary analysis. (...) Under Article 120 of the Criminal Code, the person who "applies a measure of mass destruction" and under Article $121 \S 1$ of the Criminal Code the person who places "mass extermination measures" on the market is criminally liable. After all, it would be absurd to claim that the manufacture, acquisition or transfer of a single missile with a nuclear charge "contrary to the prohibitions of international law or the provisions of the Act" is, according to the legislature's will, unpunished. (...) Conclusions resulting from the review and comparison of the content of criminal norms allow us to state that listing by the legislator the objects specified in them in plural is not an attempt to exclude liability in cases where the object in concreto is one» ${ }^{16}$.

It is easy to see that the context of the use of words is crucial, and not necessarily their number. Of course, gender/number canon can be useful in many situations, but not in all situations. Restrictive compliance with the rule could often lead to a result that runs counter to the legislative intention available by other means.

\footnotetext{
${ }^{16}$ Resolution of the Supreme Court of 21-XI-2001, I KZP 26/01, OSNKW 2002/1-2/4.
} 


\section{IV.3. Ejusdem generis}

In accordance with contextual canon, where general words follow an enumeration of two or more things, they apply only to persons or things of the same general kind or class specifically mentioned (Garner \& Scalia, 2012, p. 199). Anglo-Saxon courts have been applying the rule for hundreds of years and still often apply it (Garner \& Scalia, 2012, p. 200). The Polish courts are also keen to follow this canon ${ }^{17}$.

To use the canon ejusdem generis, you first have to determine what will be the same kind, and thus determine the genus (Eskridge, Frickey \& Garrett, 2004, pp. 95-96). You need at least two words to assess the genus (Samuels, 1984, p. 181). As the Polish Supreme Administrative Court noted, if the legislator, in order to specify the scope of the expression to be defined, listed objects belonging to this category in an exemplary manner, the assessment and qualification of other objects should omit those that do not show significant (generic) similarity to the objects listed. In the case in question, it considered that:

«The classification of free-standing antenna masts, free-standing advertising equipment permanently attached to the ground, free-standing industrial installations or technical devices as structures indicates that the distinguishing feature consisting in the attachment of a given device to the ground has been assigned significant importance by the legislature» ${ }^{18}$.

It is difficult to determine which designators have significant similarities based on some objective criteria. It depends on the assessment of the interpreter. The purpose of the Act may be useful for this decision (Popkin, 2007, p. 75). On the other hand, the object can also override or destroy the genus (Samuels, 1984, p. 181).

Ejusdem generis is not a magic spell, but a hint that is not always easy to use. All language canons are based on certain assumptions about how the legislator creates the law or what the properties of language communication

\footnotetext{
17 «In the concept of other public places, on the basis of the argument of ejusdem generis" ("of the same type"), therefore, other than directly mentioned places for communication should be included, there are internal roads of universal accessibility» (Sentence of the Voivodeship Administrative Court in Gliwice of 10-III-2014, II SA/Gl 1360/13, LEX n ${ }^{\circ}$ 1733957). In view of the interpretative rule ejusdem generis ("same type"), it should be assumed, in the opinion of the Court of First Instance, that also "other reasons" a regional installation cannot accept waste should be limited to cases with the characteristics of random events, independent of actions and decisions of the interested entities (cfr. Sentence of the Supreme Administrative Court of 3-II-2017, II OSK 1256/15, LEX n 2253601).

${ }^{18}$ Sentence of the Supreme Administrative Court of 26-VIII-2010, II OSK 1297/09, LEX $\mathrm{n}^{\mathrm{o}} 1613214$
} 
are in general. Antonin Scalia and Bryan A. Garner (2012) note that no interpretive canon is absolute (pp. 59-62). Notwithstanding ejusdem generis is not a ready-made answer, it is always a tip.

\section{IV.4. Presumption of Consistent Usage}

According to that presumption, a word or phrase is presumed to bear the same meaning throughout a text; a material variation in terms suggests a variation in meaning (Garner \& Scalia, 2012, p. 170). As provided for in $\S$ 10 of Polish Rules of normative technique, the same terms are used to denote the same concepts, and different concepts are not marked with the same terms. Referring to the assumption that the legislator consistently uses certain terminology in legal acts, two prohibitions are formulated in Polish jurisprudence: the prohibition of synonymous interpretation and the prohibition of homonymous interpretation.

Polish courts often refer to the prohibition of synonymous interpretation ${ }^{19}$, but the directive is not absolute, because the application of this rule cannot be dissociated from the specific nature of a particular regulation and the objectives pursued by it (Morawski, 2010, p. 119). For instance, the Australian Acts Interpretation Act 1901 states in section 15 AC: where (a) an Act has expressed an idea in a particular form of words; and (b) a later Act appears to have expressed the same idea in a different form of words for the purpose of using a clearer style; the ideas shall not be taken to be different merely because different forms of words were used.

For example, in one of the verdicts, the Supreme Administrative Court stated that the concept of "wholesale value", which was used in article 92.4 of the Act of 26 October 1982 on Upbringing in Sobriety and Counteracting

\footnotetext{
${ }^{19}$ Here are two of many examples that show how Polish courts refer to the aforementioned rule to select one of the interpretative hypotheses that occur:
}

«Since the legislator places two concepts of firearms (combat and hunting weapons) side by side in the content of the legal norm, the prohibition of a synonymous interpretation can only mean that these different phrases cannot be given the same meaning» (Sentence of the Supreme Administrative Court of 6-III2014, II OSK 2407/12, LEX n 1495284).

«The case of not taking up employment or other gainful employment due to the need to provide permanent care cannot be equated with resignation from employment or other gainful employment within the meaning of Art. 16a (1) of the A.C.C. Such an interpretation is justified by the fact that the legislature makes a clear distinction between those two concepts in Art. 17 (1) of the CEU and the consequent interpretative directive in the form of the so-called "prohibition of synonymous interpretation"» (Sentence of the Voivodeship Administrative Court in Bydgoszcz of 8I-2014. II SA/Bd 1485/13, LEX n ${ }^{\circ}$ 1457874). 
Alcoholism covers not only the value of sales of alcoholic beverages which were purchased by the entrepreneur and subsequently resold, but also the value of sales of alcoholic beverages which were produced by the entrepreneur and sold to entities holding permits referred to in article 18.1 of the Act. In the opinion of the Supreme Administrative Court, there are no grounds for interpreting the term "sales value" used in article 92.3 of the Act and the term "wholesale value" used in article 92.4 thereof in a different manner.

«This is due to the fact that both of the above-mentioned provisions de facto express one standard, although for editorial reasons the standard has been included in two separate units of the legal text (i.e., in two paragraphs of the same article). This standard stipulates that for entrepreneurs whose sales value in the preceding year did not exceed PLN 1.000.000 the fee for issuing the permit is PLN 4.000, while for entrepreneurs whose sales value in the preceding year exceeded PLN 1,000,000, the fee is $0.4 \%$ of the sales value in the preceding year. In other words, the provision of Art. 92.4 is "further" (continuation) of the regulation expressed in Art. 92 par. 3, because it defines the method of calculating the fee for entities whose sales value in the preceding year exceeded PLN 1.000.000. Assuming, in accordance with the prohibition of synonymous interpretation, that in Art. 92 par. 3 the basis for calculating the fee would be a different value than in Art. 92 par. 4, would be contrary to the principles of rationality and the intention of the legislator» ${ }^{20}$.

The courts also very often invoke the prohibition of homonymous interpretation ${ }^{21}$. This position is also presented by the jurisprudence, recognizing that if the legislator wants to give the same expression different meanings, and thus to waive the ban on homonymous interpretation, he should clearly state this in the legal text ${ }^{22}$. However, it should be noted that while the directive of terminological consistency is observed rather uniformly in the same legal act, there are relatively numerous derogations in different normative acts or different branches of law. Exceptions can be made to this rule

20 Sentence of the Supreme Administrative Court of 29-XI-2011, II GSK 1120/10, ONSAiWSA 2013/2/36.

${ }^{21}$ «According to the prohibition of homonymous interpretation, the same expressions cannot be understood differently within a single act (or even within the same chapter)» (Order of the Provincial Administrative Court in Gliwice of 13-II-2017, I SA/Gl 115/17, LEX n²219792).

«It cannot be considered that in one act (the Local Government Employees Act), in two paragraphs of the same Art. 36, the legislator has made such a glaring departure from the principle of terminological consequences and used the phrase special allowance in two different meanings» (Sentence of the Voivodeship Administrative Court in Gorzów Wielkopolski of 5-XII-2018, II SA/Go 772/18, LEX n 2593212).

${ }^{22}$ CT resolution of 29-I-1992 (Connecticut). 
if it is justified by the different functions of the same terms in different areas of law: for example, there are differences in the meaning of the term "document" in criminal and civil law or the term "benefit" in tax and civil law ${ }^{23}$.

Placing the presumption of a consistent usage in a normative act definitely strengthens its position. Of course, it should also be borne in mind that the practice does not always follow the precept, as Sein and Sollen are two different spheres.

Antonin Scalia and Bryan A. Garner (2012) note that the presumption of consistent usage more than most other canons assumes a perfection in drafting that actually is not often achieved: «because it is so often disregarded, this canon is particularly defeasible by context» (pp. 170-171).

\section{IV.5. Prefatory-Materials Canon}

The title and headings, as well as the preamble, purpose clause, or recital are generally considered to be permissible indicators of meaning. Polish courts often emphasize that the construction of the act, its title and structure are an important guideline for interpreters ${ }^{24}$.

\footnotetext{
${ }^{23}$ Sentence of the Voivodeship Administrative Court in Gorzów Wielkopolski of 5-XII2018, II SA/Go 772/18, LEX n 2593212.

${ }^{24}$ As the following examples show, Polish courts often refer to so-called argumentum a rubrica.
}

«Article 37 (1) of the Code of Commercial Partnerships and Companies cannot be read in isolation from Art. 46 (3) of the Code of Commercial Partnerships and Companies, which can be found in Section III, Proceedings before the provincial administrative court. Reaching for an argument a rubrica of Art. 46 (3) of the Code of Civil Procedure leads to the conclusion that the term "case" used in Art. 37 (1) of the Code of Civil Procedure concerns administrative court proceedings initiated by a specific complaint. Thus, when performing the first action in a given case, formally understood as a given administrative court proceeding, a power of attorney or a debt copy thereof should be submitted each time» (Decision of the Supreme Administrative Court in Warsaw of 24 October 2012, II FSK 1945/12, LEX n 1269942).

«This provision should be read taking into account the place where it is placed in the Construction Law (argument $a$ rubrica), i.e., that it is in the chapter devoted to the maintenance of buildings» (Sentence of the Supreme Administrative Court in Warsaw of 23-I-2018, II OSK 861/16, LEX n 2466887).

«The point of view presented, anchored in what is probably the most important directive of linguistic interpretation, i.e., the presumption of general language (a given term should be given the same meaning as it has in general language, unless important reasons oppose it), finds strong support in systemic interpretation. In its view, the legal provisions must be interpreted in view of their place in the internal system of the legal act in the first place (argumentum a rubrica). The term "burglary", this should be particularly emphasized, is used in the Criminal Code only in connection with the seizure of property for the purpose of 
It seems that in these kinds of parts of the text, especially in preambles, we primarily look for the purpose and subject of an act. In this context, the preambles and exposiciones de motivos deserve special attention.

Exposiciones de motivos are something specific only to Latin American countries and Spain (Cerdeira Bravo de Mansilla, 2015, p 17). According to the Spanish Rules of Normative Technique, preliminary draft laws and draft royal legislative decrees, as well as laws (decrees) already enacted, are divided into three parts, the first of which is the exposición de motivos, which describes the content of the law, indicating its objectives and motives as well as the facts preceding it. Spanish Judicature often refers to exposiciones de motivos ${ }^{25}$. As it is argued in the jurisprudence of the Spanish Constitutional Court, although preambles or exposiciones de motivos are not of normative value ${ }^{26}$, they serve as a criterion of interpretation allowing to know the will of the legislator ${ }^{27}$ and to make a purposive interpretation ${ }^{28}$.

misappropriation, i.e., theft» (Supreme Court decision of 5-XII-2013, case $\mathrm{n}^{\circ}$ II KK 212/13, OSNKW 2014/5/38).

${ }^{25}$ Just to mention a few rulings: the Sentence of the Tribunal Supremo of 26 October 2017 (STS 3734/2017), in which the Court explains that it is clear from the exposición de motivos that the Spanish legislature has, of its own free will, moreover, complied with the requirements of the Transport Directive (referred to in the sentence) and extended the principles of good regulation to other sectors; Sentence of the Audiencia Nacional of 18 October 2017 (SAN 3979/2017), in the exposición de motivos case cited above, it was clear which entities are eligible for funding; Sentence of the Tribunal Supremo of 16 October 2017 (STS 3530/2017), in which the Supreme Court took a closer look at the right to public information, among other things, in the context of the costs that RTVE has incurred as a result of Spain's participation in the 2015 Eurovision competition. The Court found that the exposición de motivos gave rise to a broad understanding of the right of access to public information a right that is enjoyed by all persons who can exercise it without justifying their claim and can only be limited where it is due to its own nature. Thus, the legislator obliges any limitation of this right to be interpreted restrictively. Sentence of the Tribunal Supremo of 28 June 2017 (STS 2497/2017), in which the court states that any doubts that might arise in relation to the legal basis of the judgment are dispelled by reading the preamble to the Penal Code, in which the legislator clearly explains his willingness to introduce an aggravated type of theft, referring to the social context and drawing attention to the objectives he wants to achieve.

${ }^{26}$ Sentence of the Tribunal Constitucional of 23-VII-1998 (173/1998), BOE $n^{\circ} 197$ of 18VIII-1998; Sentence of the Tribunal Constitucional of 4 October 1990, (150/1990), BOE ${ }^{\circ}$ 266 of 6-XI-1990; Sentence of the Tribunal Constitucional of 12-XI-1981, (36/1981), BOE $\mathrm{n}^{\circ} 277$ of $19-\mathrm{XI}-1981$.

${ }^{27}$ Sentence of the Tribunal Constitucional of 6-VII-2006 (222/2006), BOE $\mathrm{n}^{\circ} 185$ of 4VIII-2006; Sentence of the Tribunal Constitucional of 12-XI-1981 (36/1981), BOE $\mathrm{n}^{\circ} 277$ of 19-XI-1981.

${ }^{28}$ Sentence of the Tribunal Constitucional of 20-IV-2009 (90/2009), BOE n ${ }^{\circ} 111$ of 7-V-2009; Sentence of the Tribunal Constitucional of 7-IV-2005 (83/2005), BOE $\mathrm{n}^{\circ} 111$ of 10-V-2005. 
The Spanish Supreme Court also made it clear that the legal value of exposición de motivos does not consist in the fact that it is a legal disposition, but in the fact that it is an interpretative guidance ${ }^{29}$. It should be noted that the use of exposiciones de motivos is sometimes criticised in the literature on the grounds that it violates the principle of lex iubeat, non suadeat, non doceat, non laudat, it is noted that the law should be explained in a way that is self-explanatory, by using the right wording and appropriate regulation, and not by resorting to any additional explanations that are not of normative value but are contained in the text (Santaolalla López, 1991, p. 59). Exposiciones de motivos are sometimes considered only as a relic of the former authoritarian system (Santaolalla López, 1991, p. 56), but there are also opposing opinions that consider the exposiciones to be a useful part of the text, which facilitates a better understanding of the law and whose advantage is that it is designed, discussed, voted on and changed (Cerdeira, 2015, p. 12).

The role of the preamble is governed by a number of interpretive rules applicable worldwide ${ }^{30}$. Polish doctrine notes that preambles are usually contained in constitutions or international agreements, whereas in laws preambles are nowadays rare - in Poland they were more often included in normative acts during the period of the People's Republic of Poland (Stefaniuk, 2009, p. 32). The rarity of applying similar solutions in legal texts results from the fact that, as stated in $\S 11$ of the Polish Rules of normative technique, the act shouldn't include statements which do not serve to express legal norms, in particular appeals, postulates, recommendations, warnings and justifications for the formulated norms.

\section{LANGUAGE AND INTENTION}

In both case-law and normative acts, priority is given to the meaning of the words used in legal texts, usually their obvious, natural or plain meaning and the various intrinsic aids, which include linguistic canons. If language tools were to be prioritized over other tools, their priority is undoubtedly not that they prevail in a conflict situation (see Riofrío Martínez-Villalba, 2020, p. 218), but on the contrary: they are rather presumptions that may be rebutted than mandatory rules sensu stricto. Chronologically, the first step is to read the text, but the answer to the question of what kind of tools should be given priority cannot be made in

\footnotetext{
${ }^{29}$ Sentence of the Tribunal Supremo of 23-II-2012 (STS 1478/2012).

${ }^{30}$ See Art. 13 of the Interpretation Act of Canada, Art. 10 c) of the Maldivian Interpretation Act; Art. 5.3 of the Interpretation Act of New Zealand, Art. 40 of the Loi d'Interprétation of Quebec.
} 
abstracto. By invoking a canon to decide a case, a judge «is saying "I am not sure what the optimal policy is, but the legal culture has supplied me with a sophisticated tool that generates a result in this case, and I am going to abide by the outcome generated by that tool"» (Macey \& Miller, 1992, p. 663). Dictionaries or linguistic canons can be useful tools of interpretation, but they are not the direction of a search, but only one of the ways of conducting it - not better or more objective than other ways. As Macey and Miller point out, using canons is convenient.

It seems that interpretative provisions referring to the natural and obvious meaning of a legal text have, at least to some extent, a symbolic dimension - one (and of course not only) of their aims is to give the impression that the understanding of interpretative texts is something generally available to the average language user. But it's not the case.

No text by itself constrains interpretation (Rapaczyński, 1988, p. 177). It is worth noting that unambiguity or ambiguity in general language does not mean unambiguity or ambiguity in legal language (Tobor, 2013, p. 30). The pure fact that «the sentence is grammatical has nothing to do with whether the legislature committed an error in drafting» (Solan, 2011, p. 1042). Neither ambiguity nor unambiguity of concepts contained in legal texts can be established by means of linguistic interpretation or dictionary (Tobor, 2013, p. 184). Sometimes a word in conventional use is ambiguous, while the context of its use eliminates this ambiguity (see Marmor, 2013, p. 21). It may also work the other way round, the same text may be clear in one situation and raise doubts in another, so instead of distinguishing between easy and difficult laws, we often talk about easy and difficult cases (see Dworkin, 1986, pp. 352-356).

The law is interpreted and applied in the context of legal culture and tradition (Zirk-Sadowski, 1994). If we were to compare the law to a game, one might have the feeling that it is a game that an ordinary citizen always plays for the first time: they know the occasional rule of thumb, however, there comes a time when they have to rely on instructions, often very complex ones, or on an experienced player (Konca, 2019, pp. 295-296). Tomasz Gizbert-Studnicki (2009) notes that «even excellent linguistic competence is not a sufficient condition for understanding legal texts» (p. 15), the communication competence in the field of law, which includes, inter alia, the ability to reconstruct norms from different elements of a legal text and knowledge of the rules of legal interpretation are also necessary (Gizbert-Studnicki, 2009, pp. 13-15). Tomasz Pietrzykowski emphasizes that legal reasoning has an expert character, and it is not only about differences in knowledge, but also about the course of reasoning determined by operationalised skills of recognising typical problems and their correct 
solutions (Pietrzykowski, 2012, pp. 225-228). As Zygmunt Tobor (2010) points out:

«The basic question in an interpretative discourse is not how? but what? The answer to the question of what is simple. It will always be the intention of the legislator. If we give a different answer to the question of what, we will define activities that have little to do with legal interpretation. It is an analytical consequence, resulting from the concept of law» (p. 194).

Richard Ekins and Jeffrey Goldsworthy (2014) note that «application of interpretive maxims such as noscitur a sociis, ejusdem generis, expressio unius, and so on, makes sense only on the assumption that they sometimes help us understand the intention that guided the framing of a provision» ( $\mathrm{p}$. 54). I would say that the linguistic interpretative directives have rather presumptive than mandatory character (Jellum, 2009, pp. 852-854). This presumption can be overturned, for example, by referring to legislative history (Eskridge, Frickey \& Garrett, 2004, pp. 95-96). In abstracto, legislative materials are no worse, if not better, than dictionaries, because unlike dictionaries, they are written by the legislator himself (Tobor, 2019). Victoria Nourse (2016) says that without legislative context, statutory texts can become entirely arbitrary (p. 8).

Most intrinsic sources are based on certain assumptions about how the legislator should construct the text. However, it is not certain whether the legislator actually uses the same canons as the interpreter (Gluck \& Bressman, 2013, pp. 901-1026). The Polish Supreme Court is of the opinion that the firmly expressed priority of the linguistic interpretation could be approved only in conditions of high coherence of the legal system and legislative discipline of the legislator itself. When these conditions are not met, linguistic interpretation produces uncertain results and must be supported by systemic and functional interpretation ${ }^{31}$.

Of course, we cannot reduce the primacy of lawmaker's intention to absurdity. Stanley Fish (2005) remarks that «if it comes to light that those who enacted the rule meant by "no vehicles in the park" "no dogs in the city," then that is what the rule means» (p. 638). The question is, how is this supposed to come to light? This is where the role of linguistic interpretation is particularly important. The text of the provision shall be the point of reference for all the proposed meanings and language shall constitute the limit of interpretation, at least in terms of its scope (Chodun \& Zieliński, 2010, p. 91). Particularly in the situation of a disagreement, a court must take into account the serious doubts faced by the reader of the text who is not a

${ }^{31}$ Sentence of the Supreme Court of 20-VI-1995, ref. III ARN 22/95, OSNP 1995/24/297. 
professional. For instance, sometimes court adopts a technical meaning, but stresses that it was fully justified that the average reader may have understood the expression in its lay meaning (Popkin, 2007, pp. 261-262).

\section{CONCLUSIONS}

1. There is much talk about the priority of linguistic interpretation. Meanwhile, the interpretation is always linguistic - it concerns the language, it is done on the language. At the same time, it is never only linguistic. Each meaning appears in some context. The rigid separation of linguistic and extra-linguistic interpretation is an artificial operation that causes more problems than it solves.

2. An interpretation is made when doubts appear, and they appear in the language. If the text is ambiguous, the dictionary will not solve interpreter's problems. Language is a tool, not a solution. The way the legislator uses this tool is a very important clue, but it is not always certain (the legislator makes mistakes, differentiates the legislative technique used, etc.) and does not always provide an answer, it rather puts the question.

3. Linguistic canons do not always solve interpretation problems - they often create them.

4. It should be added that the respective position of the language canons is not always clear. Canons of interpretation, as opposed to the order to follow the intention of the legislator, are not law. It is the legislator who creates the law. Its authority is directly derived from the constitution. Meanwhile, the position of language canons and other language tools is often at least unclear. This does not mean that they are useless. If they are based on the knowledge of how the law is created and how the communication process is carried out, they are important interpretative guidelines.

5. When looking at a text in a situation of dispute, two parties can see it completely different, depending on what understanding each of them would like to adopt. The text then becomes like a Necker cube. We want to believe that the court has the key to see this cube in the right perspective. The language tools seem to be an objective key, independent of the perspective of either side. It is clear that the meaning should be based on certain conventions that will be as clear as possible to as many people as possible - after all, one of the basic requirements for legal texts is their communicativeness. 
6. The language alone is neither sufficient to state nor to clarify doubts. Doubts about the meaning of the text, as well as its understanding, appear not in the language itself, but in a broader context.

7. The most important thing is to set this context well. The right context is the legislative context - the key to finding the right guidance is the main aim of the search, which is to discover the intentions of the legislator.

8. Most intrinsic sources are based on certain assumptions about how the legislator should construct the text. For this reason, among other things, the linguistic interpretative directives have rather presumptive than mandatory character. At the same time, this presumption may be stronger or weaker, more or less precise determined etc. For example, if the legislature indicates the official dictionary it uses, the use of a dictionary, and this particular one, is more strongly justified than if there is no such provision.

9. Since no interpretative canon is absolute, language canons are not able to take from judges the responsibility for their decisions. Canons are supposed to help us, but they don't decide for us. Of course, it is not that linguistic aids are not useful at all.

10. In my opinion, depending on what kind of intrinsic aid is involved and the situation, such resources can function in three ways. (i) They can make "first impression". Some say that the first impression is the most important. The first impression may be mistaken, but it still remains our point of reference. (ii) They can confirm what appears to be clear as an additional argument for a given meaning. (iii) They may be an argument in favour of a certain meaning in some interpretative situations, if used in the correct context and unless another argument proves stronger. Providing criteria for assessing which argument is better would require more space than this work allows. At this point it is enough to stress that it is impossible to set the language in abstracto in the first place.

To conclude, Lord Scarman's statement that many rules of statutory interpretation are useful servants, but bad masters (Samuels, 1984, p. 180) is still valid today. It should be remembered that no interpretive aids can be abused. Both the court and the lawmaker are faced with the task of making good use of intrinsic sources. There is no doubt that for directives adopted by the legislator to be actually applied, the legislator must take into account how they have been applied so far. If lawyers are aware of certain discrepancies that are associated with the application of linguistic canons and dictionaries and treat intrinsic sources not as a tool of manipulation, but as one of the ways to discover the intention of the legislator, they are able to make good use of them. 


\section{REFERENCES}

Andreucci Aguilera, R. (2008). Los conceptos de la corte Suprema sobre interpretación de la ley a través de sus sentencias. Nomos, 1, 11-39.

Australia (1901). Acts Interpretation Act, as amended.

Bielska-Brodziak, A., \& Tobor, Z. (2007). Słowniki a interpretacja tekstów prawnych. Państwo i Prawo, 5, 20-33.

Bielska-Brodziak, A., Tobor, Z., \& Żmigrodzki, P. (2008a). Co każdy prawnik o słownikach wiedzieć powinien. Przegląd Sądowy, 7-8, 79-95.

Bielska-Brodziak, A., Tobor, Z., \& Żmigrodzki, P. (2008b). Opis semantyczny leksemów w słowniku ogólnym i jego doniosłość prawna. Język Polski, 88, 3-13.

Canada (1985). Interpretation Act (R.S.C., 1985, c. I-21), as amended.

Carston, R. (2013). Legal Texts and Canons of Construction: A View from Current Pragmatic Theory. In Freeman, M., \& Smith, F. (Eds.), Law and Language, 8-33. Oxford Press.

Cerdeira Bravo de Mansilla, G. (2015). Principios, realidad y norma: el valor de las exposiciones de motivos (y de los preámbulos). Editorial Reus.

Chile (2000). Código Civil Chileno, as amended.

Choduń, A., \& Zieliński, M. (2009). Aspekty granic wykładni prawa. In Miemiec, W. (Ed.), Ksiega jubileuszowa Profesora Ryszarda Mastalskiego: Stanowienie i stosowanie prawa podatkoweg, 84-95. Oficyna Wydawnicza Unimex.

Colombia (1887). Código Civil Colombiano, as amended.

Czelakowska, A., Kubicka, E., \& M. Klubińska, M. (2016). Słowniki przed sądem. Wykorzystanie dzieł leksykograficznych w orzeczeniach sądowych. LingVaria, 21, 45-64.

Dworkin, R. (1986). Imperium prawa. Wolters Kluwer Polska.

Ecuador (1855). Código Civil Ecuatoriano, as amended.

Ekins, R., \& Goldsworthy, J. (2014). The Reality and Indispensability of Legislative Intention. Sydney Law Review, 36 (39), 39-68.

Eskridge Jr., W., Frickey, P., \& Garrett, E. (2004). Cases and Materials on Legislation: Statutes and the Creation of Public Policy. West Academic Press.

Fish, S. (2005). There is No Textualist Position. San Diego Law Review, 42, 629-650.

Gizbert-Studnicki, T. (2009). Postulat zrozumiałości tekstów prawnych a dostęp do prawa. In Mróz, A., Niewiadomski, A., \& Pawelec, M. (Eds.), Prawo i język, 9-18. Wydawnictwo UKW. 
Gluck, A., Bressman, R., \& Shultz, L. (2013). Statutory Interpretation from The Inside: An Empirical Study of Congressional Drafting, Delegation, and the Canons: Part I. Stanford Law Review, 65, 901-1026.

González, C. E. (2011). Turning Unambiguous Statutory Materials into Ambiguous Statutes: Ordering Principles, Avoidance, and Transparent Justification in Cases of Interpretive Choice. Duke Law Journal, 61, 583-649.

Ireland (2005). Interpretation Act, as amended.

Italy (1942). Disposizioni sulla legge in generale lub preleggi/disciplina preliminare al Codice Civile, Royal Decree of 16 March 1942, $\mathrm{n}^{\circ}$ 262, as amended.

Jellum, L. D. (2008). Mastering Statutory Interpretation. Carolina Academic Press.

Jellum, L. D. (2009). Which is to be master, the judiciary or the legislature? When statutory directives violate separation of powers. UCLA Law Review, $56,837-898$.

Jellum, L. D., \& Hricik, D. C. (2009). Modern Statutory Interpretation. Carolina Academic Press.

Kirchmeier, J., \& Thumma, S. A. (1999). The Lexicon Has Become a Fortress: The United States Supreme Court's Use of Dictionaries. Buffalo Law Review, 47, 227-561.

Konca, P. (2019). El jurista como “traductor” del lenguaje jurídico al lenguaje de los legos. Formulación comprensible de las motivaciones de resoluciones judiciales. Revista de Derecho Procesal, 2019 (1), 295311.

Krishnakumar, A. (2015). Dueling Canons. Duke Law Journal, 65, 905-1006.

Lee, T. R., \& Mouritsen, S. C. (2017). Judging Ordinary Meaning. The Yale Law Journal, $127,788-879$.

Llewellyn, K. N. (1950). Remarks on the Theory of Appellate Decision and the Rules or Canons About How Statutes Are to Be Construed. Vanderbilt Law Review, 3, 395.

Macey, J. R., \& Miller, G. P. (1992). Canons of Statutory Construction and Judicial Preferences. Vanderbilt Law Review, 45, 647-672.

Maldives (2011). Interpretation Act (Act no 4/2011).

Marmor, A. (2013). Varieties of Vagueness in the Law. USC Legal Studies Research, 128.

Morawski, L. (2002). Wykładnia w orzecznictwie sądów. Toruń.

Morawski, L. (2010). Zasady wykładni prawa. Toruń.

Municzewski, A. (2004). Reguły interpretacyjne w działalności orzeczniczej Sądu Najwyższego. Szczecin.

New Zealand (1999). Interpretation Act ( $\left.\mathrm{n}^{\circ} 85\right)$, as amended. 
Nourse, V. (2016). Misreading Law, Misreading Democracy. Harvard University Press.

Núñez Vaquero, A. (2016). Breve ejercicio de teoría (realista) de la interpretación: veintitrés problemas interpretativos sobre la regulación del Código Civil chileno sobre la interpretación. Ius et Praxis, 22 (1), 129-164.

Pietrzykowski, T. (2012). Intuicja prawnicza. W stronę zewnętrznej integracji teorii prawa. Difin.

Poland (1992). CT Resolution of 29 January 1992.

Poland (1995). Sentence of the Supreme Court of 20 June 1995, ref. III ARN 22/95, OSNP 1995/24/297.

Poland (2001). Resolution of the Supreme Court of 21 November 2001, I KZP 26/01, OSNKW 2002/1-2/4.

Poland (2002). Ordinance of the Prime Minister of 20 June 2002.

Poland (2003). Supreme Court Sentence of May 16, 2003, II KK 65/03, LEX n ${ }^{\circ} 78379$.

Poland (2005). Sentence of the Supreme Administrative Court of 22 November 2005, ref. II FSK 1058/05, LEX nº 849612.

Poland (2010). Sentence of the Supreme Administrative Court of 26 August 2010, II OSK 1297/09, LEX nº 1613214.

Poland (2011a). Decision of the Supreme Administrative Court of 20 January 2011, II GSK 1496/10, LEX nº 742900.

Poland (2011b). Sentence of the Voivodeship Administrative Court in Wrocław of June 14, 2011, file I SA/Wr 443/11, LEX nº 991946.

Poland (2011c). Sentence of the Supreme Administrative Court of 29 November 2011, II GSK 1120/10, ONSAiWSA 2013/2/36.

Poland (2012). Decision of the Supreme Administrative Court of 24 October 2012, II FSK 1945/12, LEX n ${ }^{\circ} 1269942$.

Poland (2013). Supreme Court Decision of 5 December 2013, II KK 212/13, OSNKW 2014/5/38.

Poland (2014a). Sentence of the Voivodeship Administrative Court in Bydgoszcz of 8 January 2014, II SA/Bd 1485/13, LEX nº 1457874.

Poland (2014b). Sentence of the Supreme Administrative Court of 6 March 2014, II OSK 2407/12, LEX n ${ }^{\circ} 1495284$.

Poland (2014c). Sentence of the Voivodeship Administrative Court in Gliwice of 10 March 2014, II SA/Gl 1360/13, LEX nº 1733957.

Poland (2017a). Sentence of the Supreme Administrative Court of February 3, 2017, II OSK 1256/15, LEX nº 2253601.

Poland (2017b). Sentence of the Supreme Administrative Court of 12 October 2017, I OSK 829/17, LEX nº 2404398. 
Poland (2018a). Sentence of the Supreme Administrative Court of 23 January 2018, II OSK 861/16, LEX n ${ }^{\circ} 2466887$.

Poland (2018b). Sentence of the Voivodeship Administrative Court in Białystok of 8 November 2018, II SA/Bk 547/18, LEX nº 2576541.

Poland (2018c). Sentence of the Voivodship Administrative Court in Gorzów Wielkopolski of 28 November 2018, II SA/Go 779/18, LEX n ${ }^{\circ} 2592695$.

Poland (2018d). Sentence of the Voivodeship Administrative Court in Gorzów Wielkopolski of 5 December 2018, II SA/Go 772/18, LEX nº 2593212.

Popkin, W. (2007). A dictionary of statutory interpretation. Carolina Academic Press.

Posner, R. (1993). The Problems of Jurisprudence. Harvard University Press.

Quebec (1867). Loi d'Interprétation, as amended.

Rapaczyński, A. (1988). The ninth amendment and the unwritten constitution: The problems of constitutional interpretation. Chicago-Kent Law Review, 64 (1), 177-210.

Riofrío Martínez-Villalba, J. C. (2020). Alcance y límites del principio de jerarquía. Criterios para jerarquizar derechos, valores, bienes y otros elementos. Derecho PUCP, 84, 189-222. DOI: https://doi.org/10.18800/derechopucp.202001.007.

Rynd, A. J. (1991). Dictionaries and the interpretation of words: a summary of difficulties. Alberta Law Review, 29 (3), 712-717.

Samuels, A. (1984). The Eiusdem Generis Rule in Statutory Interpretation. Statute Law Review, 180-183.

Santaolalla López, F. (1991). Exposiciones de motivos de las leyes: motivos para su eliminación. Revista Española de Derecho Constitucional, 11 (33), 47-64.

Scalia, A., \& Garner, B. A. (2012). Reading Law: The Interpretation of Legal Texts. Thomson West.

Sinclair, M. (2006). Only A Sith Thinks Like That: Llewellyn's "Dueling Canons," One to Seven. New York Law School Law Review, 50, 919-992.

Solan, L. M. (2011). Statutory Interpretation, Morality, and the Text. Brooklyn Law Review, 76, 1033-1048.

Solan, L. M. (2014). Is It Time for a Restatement of Statutory Interpretation? Brooklyn Law Review, 79, 733-756.

Spain (1889). Código Civil. Real Decreto del 24 de Julio de 1889 por el que se publica el Código Civil, BOE nº 206, del 25 de Julio de 1889, BOE-A-18894763.

Spain (1981). Sentence of the Tribunal Constitucional of 12 November 1981 (36/1981), BOE nº 277, 19 November 1981. 
Spain (1990). Sentence of the Tribunal Constitucional of 4 October 1990 (150/1990), BOE $n^{\circ} 266$ of 6 November 1990.

Spain (1998). Sentence of the Tribunal Constitucional of 23 July 1998 (173/1998), BOE $n^{\circ} 197$ of 18 July 1998.

Spain (2005a). Sentence of the Tribunal Constitucional of 7 April 2005 (83/2005), BOE $n^{\circ}$ 111 of 10 May 2005.

Spain (2005b). Directrices de técnica normativa. Boletín Oficial del Estado ${ }^{\circ} 180$ del 29 de Julio de 2005, 26.878-26.890.

Spain (2006). Sentence of the Tribunal Constitucional of 6 July 2006 (222/2006), BOE $n^{\circ}$ 185 of 4 July 2006.

Spain (2009). Sentence of the Tribunal Constitucional of 20 April 2009 (90/2009), BOE $\mathrm{n}^{\mathrm{o}} 111$ of 7 May 2009.

Spain (2005). Directrices de técnica normativa. Boletín Oficial del Estado n 180 del 29 de Julio de 2005, 26.878-26.890.

Spain (2012). Sentence of the Tribunal Supremo of 23 February 2012 (STS 1478/2012).

Spain (2017a). Sentence of the Tribunal Supremo of 28 June 2017 (STS 2497/2017).

Spain (2017b). Sentence of the Tribunal Supremo of 16 October 2017 (STS 3530/2017).

Spain (2017c). Sentence of the Audiencia Nacional of 18 October 2017 (SAN 3979/2017).

Spain (2017d). Sentence of the Tribunal Supremo of 26 October 2017 (STS 3734/2017).

Spain (2020a). Sentence of the Tribunal Superior de Justicia de Cataluña, Sala de lo Civil y Penal, of 24 February 2020 (STSJ CAT 90/2020).

Spain (2020b). Sentence of the Tribunal Supremo, Sala de lo Social, of 11 March 2020 (STS 1145/2020).

Spain (2020c). Sentence of the Tribunal Supremo, Sala de lo Penal, of 7 May 2020 (STS 1298/2020).

Spain (2020d). Sentence of the Tribunal Superior de Justicia de Cataluña, Sala de lo Contencioso, of 15 May 2020 (STSJ CAT 2114/2020).

Spain (2020e). Sentence of the Tribunal Superior de Justicia de Galicia, Sala de lo Social, of 10 June 2020 (STSJ GAL 2509/2020).

Spain (2020f). Sentence of the Audiencia Nacional, Sala de lo Social, of 16 June 2020 (SAN 1162/2020).

Spain (2020g). Sentence of the Tribunal Supremo of 26 June 2020 (STS 1963/2020).

Stefaniuk, M. E. (2009). Preambuła aktu normatywnego $w$ doktrynie oraz $w$ procesie stanowienia i stosowania polskiego prawa w latach 1989-2007. Wydawnictwo Uniwersytetu Marii Curie-Skłodowskiej.

Tobor, Z. (2010). Iluzja wykładni językowej. In Lewkowicz, P. J. (Ed.), Konstytucyjne uwarunkowania tworzenia $i$ stosowania prawa finansowego $i$ podatkowego, 194-200. Temida 2. 
Tobor, Z. (2013). W poszukiwaniu intencji prawodawcy. Wolters Kluwer.

Tobor, Z. (2019). Strategia interpretacyjna jako środek komunikacji prawodawcy i sądów. Państwo i Prawo, 11, 48-64.

United Kingdom (1978). Interpretation Act, as amended.

United States (2013). Connecticut, CT Gen Stat $§ 1-2 z$.

Uruguay (1869) Código Civil Uruguayo, as amended.

Wierczyński, G. (2016). Redagowanie i ogłaszanie aktów normatywnych. Wolters Kluwer Polska.

Winter, S. L. (1990). Indeterminacy and Incommensurability in Constitutional Law. California Law Review, 78, 1444-1541.

Wronkowska, S., \& Zieliński, M. (2012). Komentarz do zasad techniki prawodawczej: z dnia 20 czerwca 2002 r. Wydawnictwo Sejmowe.

Wróblewski, J. (1959). Zagadnienia teorii wykładni prawa ludowego. Wydawnictwo Prawnicze.

Zeifert, M. (2019). Gramatyka przepisu jako przesłanka decyzji interpretacyjnej. Wydawnictwo Uniwersytetu Śląskiego.

Zieliński, M. (2002). Wykładnia prawa. Zasady, Reguły. Wskazówki. LexisNexis.

Ziembiński, Z. (1980). Problemy podstawowe prawoznawstwa. Państwowe Wydawnictwo Naukowe.

Zirk-Sadowski, M. (1994). Sposoby uczestniczenia prawników w kulturze. Ruch Prawniczy, Ekonomiczny i Socjologiczny, 56 (4), 47-52.

Żmigrodzki, P. (2003). Wprowadzenie do leksykografii polskiej. Wydawnictwo Uniwersytetu Śląskiego.

Żurowski, S. (2014). Leksykografia w pracy prawnika. In Kubicka, E., \& Kala, D. (Eds.), Kultura języka polskiego w praktyce prawniczej, 55-75. Zrzeszenie Prawników Polskich. Oddział w Bydgoszczy.

Żurowski, S. (2015). Leksykografia w pracy prawnika. Kwartalnik Sadowy Apelacji Gdańskiej, 2, 29-40. 